Law, Language, and Empire

in the Roman Tradition 
EMPIRE AND AFTER

Clifford Ando, Series Editor

A complete list of books in the series is available from the publisher. 


\section{LAW, LANGUAGE,}

AND EMPIRE IN THE

ROMAN TRADITION

CLIFFORD ANDO

\section{$\overline{\text { PENN }}$}

UNIVERSITY OF PENNSYLVANIA PRESS

PHILA DEL PHIA 
Copyright (C 20II University of Pennsylvania Press

All rights reserved. Except for brief quotations used for purposes of review or scholarly citation, none of this book may be reproduced in any form by any means without written permission from the publisher.

Published by

University of Pennsylvania Press

Philadelphia, Pennsylvania 19104-4II2

www.upenn.edu/pennpress

Printed in the United States of America on acid-free paper

IO 987665432 I

Library of Congress Cataloging-in-Publication Data Ando, Clifford, 1969-

Law, language, and empire in the Roman tradition / Clifford Ando. — Ist ed.

p. cm. - (Empire and after)

Includes bibliographical references and index.

ISBN 978-0-8122-4354-3 (hardcover : alk. paper)

I. Law-Rome-Provinces. 2. International law

(Roman law) 3. Legal polycentricity-Rome. 4. Roman law-Language. I. Title. II. Series: Empire and after. KJA29I8.A86 20II

$340.5^{\prime} 4$ - dc23 
For John Scheid 
This page intentionally left blank 